\title{
The SEM Investigation of Inconel 718 Fatigue Process at Various Loading Conditions
}

Juraj Belan ${ }^{1}$, Michal Jambor ${ }^{1}$, Lenka Kuchariková1, Eva Tillová1, Mária Chalupová1, Miloš Matvija ${ }^{2}$

${ }^{1}$ University of Žilina, Department of Materials Engineering, Faculty of Mechanical Engineering, Univerzitná 8215/1, 01026 Žilina, Slovakia.

E-mails: juraj.belan@fstroj.uniza.sk,_michal.jambor@fstroj.uniza.sk, lenka.kucharikova@fstroj.uniza.sk, eva.tillova@fstroj.uniza.sk,maria.chalupova@fstroj.uniza.sk

${ }^{2}$ Technical University of Košice, Faculty of Metallurgy, Institute of Materials, Letná 9, 04200 Košice, Slovakia. E-mail: Milos.Matvija@tuke.sk

Fracture surfaces of specimens broken by cyclic loading provide valuable information about individual stages of fatigue process. Changes in the loading conditions (character of fatigue loading, stress amplitude level, influence of cycle asymmetry ratio $R$, testing temperature, environment of test, etc.) and in the structure of tested material as well cause changes in the fatigue process, whose have effect on fracture surface resulting in change of fatigue properties. In this paper, authors describe the changes of fatigue process of nickel base superalloy Inconel 718 as a result of loading conditions change using SEM (Scanning Electron Microscopy) microfractography analysis of fractured surfaces. The various fatigue loading were, at the first, regular push-pull loading with asymmetry ratio $R=-1$ and frequency $f=$ approx. $20000 \mathrm{kHz}$ (High Frequency and High Cycles fatigue Loading - HFL) and the second was three-point flexure loading with asymmetry ratio $R=0.116 \div 0.507$ and frequency $f=$ approx. $150 \mathrm{~Hz}$ (Low Frequency and High Cycles fatigue Loading - LFL). All fatigue tests were done at room temperature.

Keywords: Fatigue process, Push-pull loading, Three-point flexure loading, SEM surface fractography, Inconel 718 alloy

\section{Acknowledgement}

The project presented in this article is supported by Scientific Grant Agency of Ministry of Education of The Slovak Republic and the Slovak Academy of Sciences, No. 1/0533/15, No. 049ŽU-4/2017 and project EU ITMS 26220220154.

\section{References}

[1] SCHAFRIK RE, WARD DD, GROH JR. In: Superalloys 718, 625, 706 and Various Derivatives, 2001. p. 1-11.

[2] C. BATHIAS, A. PINEAU, Fatigue des Matériaux et des Structures 3, Hermes science publication, (2009).

[3] D. F. PAULINIS, J.J. SCHIRRA (2001). Alloy 718 at Pratt \& Whitney - Historical perspective and future challenges, Superalloys 718, 625, 706 and derivatives, ed. by E. E. Loria, TMS, (2001).

[4] ALEXANDRE, F., DEYBER, S., PINEAU, A. (2004). Modelling the optimum grain size on the low cycle fatigue life of a Ni based superalloy in the presence of two possible crack initiation sites. In: Scipta Materialia, Vol. 50, No. 1, pp. 25 - 30. Elsevier Ltd.

[5] BOKŮVKA, O. et al. (2014). Fatigue of materials at low and high frequency loading. p. 146. EDIS University of Žilina, Žilina.

[6] CAMPBELL, F. C. (2008). Elements of Metallurgy and Engineering Alloys. p. 243 - 263. Materials Park, Ohio.

[7] ANTOLOVICH, S., D. (2015). Microstructural aspects of fatigue in Ni-base superalloys. Phil. Trans. R. Soc. A 373: 20140128. http://dx.doi.org/10.1098/rsta.2014.0128

[8] LAIRD, C. (1967). The influence of metallurgical structure on the mechanisms of fatigue crack propagation. In: Fatigue crack propagation, p. 131, ASTM STP 415, ASTM, Philadelphia.

[9] BELAN, J., KUCHARIKOVÁ, L., VAŠKO, A., TILLOVÁ, E. (2014). Metallography evaluation of IN 718 after applied heat treatment. In: Manufacturing Technology, Vol. 14, No. 3, pp. 262-267.

[10] BELAN, J., KUCHARIKOVÁ, L., TILlOVÁ, E., UHRÍČIK, M. (2015). The Overview of Intermetallic Phases Presented in Nickel Base Superalloys after Precipitation Hardening. In: Manufacturing Technology, Vol. 15, No. 4, pp. $509-515$.

[11] ASTM E112 - 96. (2004). Standard test methods for determining average grain size. ASTM Int., PA, USA.

[12] EISELSTEIN, H., L. (1965). Metallurgy of a columbium hardened nickel-chromium-iron alloy. In. ASTM Special Technical Publication, Vol. 369, pp. 62 - 79.

[13] PAULONIS, D., F., OBLAK, J., M., DUVALL, D., S. (1969). Precipitation in nickel base alloy 718. In. Trans. ASM, Vol. 62, pp. $611-622$. 
[14] CHATURVEDI, M., C., HAN, Ya-fang. (1983). Strengthening mechanisms in Inconel 718 superalloy. In. Met. Sci., Vol. 17, pp. $145-149$.

[15] SUNDARARAMAN, M., MUKHOPADHYAY, P., BANERJEE, S. (1992). Some aspects of the precipitation of metastable intermetallic phases in Inconel 718. In. Metall. Trans. A, Vol. 23, pp. 2015 - 2028.

[16] COZAR, R., PINEAU, A. (1973). Morphology of $\gamma^{\prime}$ and $\gamma^{\prime \prime}$ precipitates and thermal stability of Inconel 718 type superalloys. In.Metall. Trans., Vol. 4, pp. $47-59$.

[17] MAHADEVAN, S. et al. (2010). Evolution of $\delta$ phase microstructure in alloy 718. In. $7^{\text {th }}$ International Symposium on Superalloy 718 and Derivates (E. A. Ott, J. R. Groh et al (Ed.)), pp. 737 - 750. TMS (The Minerals, Metals \& Materials Society).

[18] TRŠKO, L., BOKU゚VKA, O. NOVÝ, F., GUAGLIANO, M. (2014). Effect of severe shot peening on ultra-highcycle fatigue of a low-alloyed steel. In. Material \& Design, Vol. 57, pp. 103 - 113, Elsevier Sci., England.

[19] BELAN, J. (2015). High frequency fatigue test of IN 718 alloy - microstructure and fractography evaluation. In. Metalurgija - Metallurgy, Vol 54, No. 1, pp. 59 - 62, Croatian Metallurgical Society.

[20] VAŠKO, A., TRŠKO, L., KONEČNÁ, R. (2015). Fatigue behavior of synthetic nodular cast irons. In. Metalurgija - Metallurgy, Vol. 54, No. 1, pp. 19 - 22, Croatian Metallurgical Society.

[21] VAŠKO, M., VAŠKO, A. (2014). Correlation between charge composition and fatigue properties of nodular cast irons. In. Applied Mechanics and Materials, Vol. 474, pp. 291-296, TTP Switzerland. 